\section{NTS 2020/41}

\author{
HR 4 februari 2020, 18/03731, ECLI:NL:HR:
} 2020:191

\begin{abstract}
Mensenhandel door echtgenote te dwingen haar opbrengsten uit prostitutiemerkzaamheden naar hem toe te sturen door haar onder druk te zetten en daarbij gebruik te maken van omstandigheid dat haar kind bij (familie van) verdachte in Roemenie verblijft, art. $273 f .1 .9 \mathrm{Sr}$. Is sprake van uitbuiting, nu Hof niet heeft vastgesteld dat echtgenote van verdachte haar merkzaamheden in prostitutie onvrijmillig verrichtte?
\end{abstract}

\section{Aantekening redactie}

In 2018 oordeelde de Hoge Raad dat de in artikel $273 \mathrm{f}$ lid 1 onder $9^{\circ} \mathrm{Sr}$ bedoelde gedragingen van degene die een ander dwingt dan wel beweegt hem te bevoordelen als in die bepaling bedoeld, eerst dan als 'mensenhandel' kunnen worden bestraft indien uit de bewijsvoering volgt dat is voldaan aan voormelde voorwaarde dat die gedragingen zijn begaan onder omstandigheden waarbij uitbuiting kan worden verondersteld. 'Uitbuiting' moet worden aangemerkt als een impliciet bestanddeel van artikel $273 \mathrm{f}$ lid 1 aanhef en onder $9^{\circ} \mathrm{Sr} .^{30}$

Onderdeel $9^{\circ}$ van het eerste lid van artikel $273 \mathrm{f} \mathrm{Sr}$ ziet op opbrengsten van seksuele handelingen en niet op handelingen met het oogmerk de ander ertoe te brengen dat zij of hij zich beschikbaar stelt tot het verrichten van seksuele handelingen, zoals in artikel $273 \mathrm{f}$ lid 1 aanhef en onder $3^{\circ} \mathrm{Sr}$. $\mathrm{Bij}$ het laatste gaat het om handelingen die de strekking hebben het slachtoffer ontvankelijk te maken voor uitbuiting, bij het eerste om het met ongeoorloofde middelen profiteren van de opbrengst uit seksuele handelingen. Het laatstgenoemde werd gezien als een vorm van uitbuiting. In deze benadering leidt de omstandigheid dat de opbrengsten van seksuele handelingen het slachtoffer 'afhandig' worden gemaakt ertoe dat het slachtoffer wordt uitgebuit, omdat het slachtoffer onvrijwillig opbrengsten afstaat en aldus niet kan beschikken over eigen financiële middelen. Dat sprake is van uitbuiting volgt dan uit het gebruik van (een combinatie van) bepaalde middelen als bedoeld in artikel $273 \mathrm{f}$ lid 1 aanhef en onder $9^{\circ} \mathrm{Sr}$ in verbinding met artikel $273 \mathrm{f}$ lid 1 aanhef en onder $1^{\circ} \mathrm{Sr}$ en betekent niet per definitie dat ook de seksuele handelingen onvrijwillig zijn verricht. De verdachte in de hier te bespreken zaak is door het hof (onder bevestiging van het vonnis van de rechtbank) veroordeeld wegens 'mensenhandel'. Het middel klaagde over de bewezenverklaring van het impliciete bestanddeel 'uitbuiting'. Het hof had vastgesteld dat de verdachte wist dat het slachtoffer werkzaam was in de prostitutie en dat de verdachte het slachtoffer in de bewezen verklaarde periode heeft gecontroleerd, haar onder zware druk heeft gezet en dwingend is geweest om ervoor te zorgen dat het slachtoffer hem geld stuurde uit de opbrengsten van die werkzaamheden, door (meermalen) te dreigen haar te vermoorden en kapot te maken, te dreigen dat hij zichzelf iets zou aandoen en dat zij hun dochter nooit meer zou zien als zij niet (meer) geld naar hem zou sturen, haar bij herhaling te berichten dat hij en hun dochter honger leden en dat er niet goed voor hun dochtertje werd gezorgd, en haar te misleiden over de omstandigheden waaronder de verdachte en hun dochter leefden in Roemenië, terwijl haar dochtertje bij (familie van) de verdachte in Roemenië verbleef. Punt was echter dat het slachtoffer haar werkzaamheden als prostituee vrijwillig verrichtte (althans dat het hof niet heeft vastgesteld dat zij deze onvrijwillig verrichtte). De dwang en misleiding zag op het afstaan van opbrengsten die vrijwillig waren verdiend. Die vrijwilligheid zou volgens de verdediging onverenigbaar zijn met het feit dat uitbuiting een (impliciet) bestanddeel is van onderdeel 9. Nou is de vraag of - en zo ja, wanneer - sprake is van 'uitbuiting' niet in algemene termen te beantwoorden, maar is dit sterk verweven met de omstandigheden van het geval. Van uitbuiting in de context van artikel $273 \mathrm{f}$ lid 1 aanhef en onder $9^{\circ}, \mathrm{Sr}$ is volgens de Hoge Raad echter niet slechts sprake als het verrichten van seksuele handelingen plaatsvindt onder omstandigheden waarbij uitbuiting kan worden verondersteld, maar ook als de wijze waarop degene die een ander dwingt dan wel beweegt hem te bevoordelen uit de opbrengst van (vrijwillig) verrichte seksuele handelingen meebrengt dat die bevoordeling plaatsvindt onder omstandigheden waarbij uitbuiting kan worden verondersteld. $\mathrm{Nu}$ in de vaststellingen van het hof als oordeel besloten ligt dat, gelet op de wijze waarop de verdachte het slachtoffer heeft gedwongen hem te bevoordelen uit de opbrengst van haar werkzaamheden in de prostitutie, die bevoordeling heeft plaatsgevonden onder omstandigheden waarbij de in de context van artikel $273 \mathrm{f}$ lid aanhef en onder $9^{\circ} \mathrm{Sr}$ vereiste uitbuiting kan worden verondersteld. Daaraan doet volgens de Hoge Raad niet af dat het hof niet heeft vastgesteld dat het slachtoffer haar werkzaamheden in de prostitutie onvrijwillig verrichtte. 